Pesq. Vet. Bras. 36(4):283-289, abril 2016 DOI: $10.1590 / \mathrm{S} 0100-736 \mathrm{X} 2016000400006$

\title{
Intramammary treatment with gentamicin in lactating cows with clinical and subclinical mastitis ${ }^{1}$
}

\author{
Thamires Martins ${ }^{2 *}$, Adriana F. Rosa ${ }^{2}$, Lívia Castelani² ${ }^{2}$ Mariana S. de Miranda², \\ Juliana R. P. Arcaro² and Claudia R. Pozzi ${ }^{2}$
}

\begin{abstract}
Martins T., Rosa A.F., Castelani L., Miranda M.S. de, Arcaro J.R.P. \& Pozzi C.R. 2016. Intramammary treatment with gentamicin in lactating cows with clinical and subclinical mastitis. Pesquisa Veterinária Brasileira 36(4):283-289. Centro Apta Bovinos de Leite, Instituto de Zootecnia, Rua Heitor Penteado 56, Centro, Nova Odessa, SP 13460000, Brazil. E-mail: martins_thamires@hotmail.com

The study evaluated the microbiological profile of milk samples collected before and after mastitis treatment with gentamicin and investigated biofilms production and antimicrobial susceptibility of Staphylococcus spp. isolated. The presence of gentamicin residues in milk after the recommended withdrawal period was also evaluated. Antimicrobial residues were analyzed by Delvotest ${ }^{\circledR}$ SP NT over a period of 12 days beginning after 24 hours the last gentamicin application. Some of Staphylococcus spp. isolates were biofilm producers (19.05\%). Staphylococcus spp. showed high levels of resistance to neomycin (16.95\%), penicillin G (10.17\%), and ampicillin (10.17\%). Multidrug resistance to all antibiotics tested was observed in $1.69 \%$ of the Staphylococcus spp. isolates. Among 1440 mammary quarter milk samples $24.95 \%$ presented gentamicin residues after the withdrawal period. Gentamicin residues were also detected in $3.8 \%$ of samples from calibrated glass recorder jar $(n=383) 4.1$ days after treatment. The indiscriminate use of antibiotics may lead to the emergence of multidrug-resistant strains as well as increasing the risk of presence of residues of these drugs in milk. These problems affect the milk quality and may become a public health problem.
\end{abstract}

INDEX TERMS: Antibiotic residues, biofilm production, mastitis treatment, multiresistance, Staphylococcus spp.

RESUMO.- [Tratamento intramamário com gentamicina em vacas com mastite clínica e subclínica durante a lactação.] Este estudo avaliou o perfil microbiológico de amostras de leite colhidas antes e após o tratamento da mastite com gentamicina e investigou a produção de biofilmes e o perfil de susceptibilidade antimicrobiana de Staphylococcus spp. isolados. Avaliou-se também a presença de resíduos de gentamicina no leite após o período de carência recomendado. Resíduos de antimicrobianos foram analisados por Delvotest ${ }^{\circledR}$ SP NT ao longo de um período de 12 dias, iniciando 24 horas após a última aplicação de gentamicina. Alguns dos Staphylococcus spp. isolados apre-

\footnotetext{
${ }^{1}$ Received on October 21, 2015.

Accepted for publication on March 4, 2016.

${ }^{2}$ Centro Apta Bovinos de Leite, Instituto de Zootecnia (IZ), Rua Heitor Penteado, 56, Centro, Nova Odessa, SP 13460-000, Brazil. *Corresponding author: martins_thamires@hotmail.com
}

sentaram produção de biofilmes (19,05\%). Staphylococcus spp. apresentaram elevados níveis de resistência à neomicina $(16,95 \%)$, penicilina G $(10,17 \%)$, e ampicilina $(10.17 \%)$. Multirresistência a todos os antibióticos testados foi observada em 1,69\% dos Staphylococcus spp. isolados. Do total de 1440 amostras de leite de quartos mamários, 24,95\% apresentaram resíduos de gentamicina após o período de carência. Resíduos de gentamicina também foram detectados em 3,8\% das amostras de balões volumétricos coletores de leite $(\mathrm{n}=383), 4,1$ dias após o tratamento. 0 uso indiscriminado de antibióticos pode levar ao aparecimento de estirpes multirresistentes bem como o aumento do risco da presença de resíduos destas drogas no leite. Esses problemas afetam a qualidade do leite e podem tornar-se um problema de saúde pública.

TERMOS DE INDEXAÇÃO: Resíduos de antibióticos, produção de biofilme, tratamento de mastite, multirresistência, Staphylococcus spp. 


\section{INTRODUCTION}

Antimicrobial agents are commonly applied to dairy cattle either to control or to prevent bacterial infections and the bovine mastitis is a leading cause of the use of these drugs (Gomes \& Henriques 2015). Bacteria species of the genus Staphylococcus are the main etiological agents of contagious mastitis due to their ability to penetrate and establish deep infection in mammary gland tissues (Peton \& Le Loir 2014). The ability of Staphylococci to form biofilms facilitates the adherence and colonization in mammary gland epithelium, also contributing to the evasion of the immunological defenses and to the difficulty of pathogen eradication, often resulting in persistent infections (Tan et al. 2009, Melchior 2011).

Misuse and overuse of antimicrobial drugs can lead to the emergence of resistant bacteria and to the presence of antimicrobial residues in milk (Gomes \& Henriques 2015). In some cases, detection of antibiotic residues can be attributed to the persistence of these drugs in milk beyond the recommended withdrawal period (Bansal et al. 2011).

Aminoglycosides are widely used in Brazil for the treatment of mastitis and no restrictions exist regarding their veterinary use. In addition, the National Sanitary Surveillance Agency (ANVISA), which is the responsible for the establishment of Maximum Residue Limit (MRL) in Brazil, does not provide recommendations regarding the upper limits for gentamicin in milk. Therefore, the MRL $(200 \mu \mathrm{g} / \mathrm{L})$ recommended by Codex Alimentarius Commission (2012) is used.

The purpose of this study was to evaluate microbiological profile of milk samples collected before and after treatment with intramammary gentamicin from cows that presented clinical and subclinical mastitis. Additional objectives were to evaluate the biofilm production and antimicrobial susceptibility profile of Staphylococcus spp. and to investigate the presence of gentamicin residues after the recommended withdrawal period.

\section{MATERIALS AND METHODS}

Ethics statement. All procedures performed in this study involving animals were in accordance with the ethical standards (Protocol 160/2010) of the Institute of Animal Science and Pastures (IZ), Ethics Commission for Experiments in Animals, Brazil.

Property milking management. The herd studied consisted of Black and White Holstein animals. These animals were milked twice a day (7 am and $3 \mathrm{pm}$ ) in a closed-loop system using a Tandem mechanical milking parlor. Before milking, the teats were cleaned with water and dried with disposable paper towel. Iodine solution was used to disinfect teats after milking. The animals were submitted to the strip cup test daily and to the California Mastitis Test (CMT) once a month to detect clinical and subclinical mastitis, respectively. Animals that presented mastitis were milked separately and its milk was submitted to bacterial isolation and antibacterial resistance profile before treatment. The milking was initiated by first lactation cows, normal cows and cows with mastitis.

Selection of animals. Sixteen lactating cows with clinical and subclinical mastitis, which had no history of disease or treatment with antibiotics during the 40 days prior to the beginning of the experiment, were selected. Before milking, the animals were submitted to the strip cup test and those whose mammary quarters secreted milk with clots and/or whose mammary gland presented visible alterations (swelling, heat, redness, and pain) were classified as having clinical mastitis (group 1). These animals were also submitted to the California Mastitis Test (CMT) and somatic cell count (SCC) to determine the occurrence of subclinical mastitis (group 2). This evaluation was performed after a minimum period of 40 days of treatment of clinical cases until the animals developed an inflammatory process (subclinical mastitis). The CMT was conducted as described by Daniel et al. (1966), assigning scores of 0 (negative), trace, 1, 2, and 3. Mammary quarters milk samples presenting viscosity starting from score one were submitted to SCC. These samples were transferred to plastic flasks containing bromothymol as a preservative and analyzed with the Somacountтм 300 (Bentley Analytical Instruments Inc., Chaska, MN, USA). The mammary quarter with an SCC $>200,000$ cells/mL milk was selected for treatment.

Treatment. Treatment consisted of intramammary infusion of gentamicin sulfate $(150 \mathrm{mg}$ in $50 \mathrm{mg}$ bromhexine hydrochloride and $10 \mathrm{~mL}$ vehicle) once a day after afternoon milking for 3 days. The drug was injected into only one mammary quarter of each animal of the two groups after antisepsis of the teat tips with $70 \%$ alcohol. The gentamicin sulfate treatment was chosen based on the widely use of this drug for mastitis treatment in Brazil. The withdrawal period of the drug recommended by the manufacturer is 4 days ( $96 \mathrm{~h}$ ) after the last application.

Collection of milk samples. For the detection of gentamicin residues, milk samples were collected from all mammary quarters (treated and untreated), from individual calibrated glass recorder jar of each animal and cooling tank of the property over a period of 12 consecutive days after the last antibiotic application. Samples were collected before the beginning of treatment with gentamicin sulfate to confirm the absence of antimicrobial residues in milk. A total of 96 mammary quarters samples were not collected after treatment due animals that presented nonsecretory mammary cells. Mammary quarter samples collected before treatment and on the last day of sampling after treatment were also used for microbiological evaluation to identify the most prevalent microorganisms in cases of mastitis and to evaluate biofilm production and the antimicrobial susceptibility profile of Staphylococcus spp. isolates. Quarter milk samples were collected into previously identified sterile tubes after washing and drying with paper towel and antisepsis with $70 \%$ alcohol. Milk from the calibrated glass recorder jars was homogenized and collected after milking of the animal. Milk samples were collected from the cooling tank after the two milkings of the day. All samples were stored frozen at $-20^{\circ} \mathrm{C}$ until the time for laboratory analysis.

Microbiological analysis. Aliquots $(10 \mu \mathrm{L})$ of the milk samples were streaked on $5 \%$ sheep blood agar plates. The plates were incubated at $37^{\circ} \mathrm{C}$, and analyzed after 24,48 and $72 \mathrm{~h}$. Provisional colony identification was based on Gram stain, morphology and hemolysis patterns. Gram-positive cocci were tested for catalase and coagulase production. Staphylococcus aureus were identified by biochemical standard tests: acetoin production, mannitol fermentation and maltose and trehalose utilization (Dowes \& Ito 2001). The milk samples were also streaked on Sabouraud dextrose agar plates containing penicillin (500 IU) and streptomycin $\left(100 \mathrm{mg}\right.$ ) for fungal identification. After incubation at 22 to $25^{\circ} \mathrm{C}$ for a period of 3 to 10 days, differences in colony morphology between filamentous fungi and yeasts were analyzed.

The antimicrobial susceptibility profile of Staphylococcus spp. was evaluated by the disc diffusion test on Mueller-Hinton agar according the CLSI (2012) using the following antibiotic discs

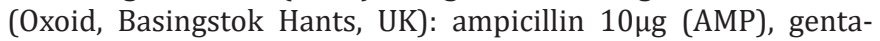

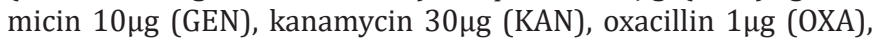

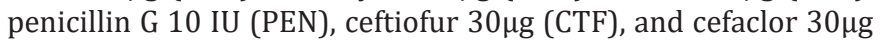
(CEC). The BSAC standardized disc susceptibility testing method 
was used to determine susceptibility to neomycin $10 \mu \mathrm{g}$ (NEO) (Andrews 2009).

Biofilm production by Staphylococcus spp. isolates was evaluated on Congo red agar (CRA) (Freeman et al. 1989). Reference strains of Staphylococcus aureus (ATCC 25,923) and Staphylococcus epidermidis (ATCC 12,228) were used as positive and negative controls, respectively.

Analysis of gentamicin residues. The presence of gentamicin residues in milk was analyzed using a commercial microbiological inhibition test (Delvotest ${ }^{\circledR}$ SP NT, DSM Foods Specialties B.V., Delft, The Netherlands). A high SCC and enzymes present in milk of animals with mastitis were identified as factors that influence the results of the Delvotest ${ }^{\circledR}$, yielding false-positive results (Andrew et al. 1997). For this propose, an aliquot ( $2 \mathrm{~mL}$ ) of the milk sample was previously heated to $82^{\circ} \mathrm{C}$ for $5 \mathrm{~min}$. in a water bath to prevent false-positive results (Kang et al. 2005). The results were interpreted according to the color of the ampoules: negative (yellow), limit of detection (yellow and purple), and positive (purple). Positive and negative controls were analyzed together with the milk samples.

Milk samples free of antimicrobial residues were spiked with different concentration of gentamicin sulfate (Sigma, St. Louis, MO, USA) solution $(10,50,100,200,300$ and $500 \mu \mathrm{g} / \mathrm{L})$ for limit of detection (LOD) determination. These spiked milk samples were analyzed in triplicate.

Statistical analysis. The chi-squared test $\left(\chi^{2}\right)$ was used to compare the frequency of strains isolated from treated and untreated mammary quarters according to the sampling period (before and after treatment), considering a 95\% confidence interval. Multivariate binary regression analysis was used to compare the elimination of gentamicin residues between groups, with group 1 (clinical mastitis) assuming a value of 0 and group 2 (subclinical mastitis) a value of 1 . Statistical analyses were performed using Minitab Statistical Software (2010), version 15.1.3.

\section{RESULTS}

\section{Microbiological profile}

Among the 210 strains isolated from milk samples of cows with clinical and subclinical mastitis, the microorganisms most frequently isolated were Corynebacterium spp. (43.81\%), Staphylococcus spp. (30.01\%) and Streptococcus spp. (22.38\%). Coagulase-negative staphylococci (CNS) were the most frequent (47.61\%) among the 63 Staphylococcus spp. isolated. The isolation frequency of Corynebac- terium spp., coagulase-positive staphylococci (CPS), and $S$. aureus was higher after treatment. Isolation of Streptococcus spp. and CNS was less frequent after treatment (Table 1). After treatment, the frequency of isolated strains was reduced by $76.9 \%$ and $33.3 \%$ in treated mammary quarters of cows with clinical and subclinical mastitis, respectively. In contrast, an increase in the frequency of isolated strains of $24.1 \%$ and $23.8 \%$ was observed in untreated mammary quarters of animals with clinical and subclinical mastitis, respectively. However, these differences observed in frequency of isolated strains between samples collected before and after treatment were not significant in treated $\left(\chi^{2}=2.231 ;\right.$ d.f. $\left.=1 ; P=0.135\right)$ and untreated $\left(\chi^{2}=0.000\right.$; d.f. $=1 ; \mathrm{P}=0.993)$ mammary quarters.

\section{Biofilm production and antimicrobial susceptibility}

Twelve $(19.05 \%)$ of the 63 Staphylococcus spp. isolates tested on CRA produced biofilms, including four coagulase-negative staphylococci $(13.33 \%)$, five coagulase-positive staphylococci $(20.83 \%)$ and three S. aureus strains (33.33\%).

Fifty-nine Staphylococcus spp. strains were submitted to antimicrobial susceptibility testing by the disc diffusion method on Mueller-Hinton agar. In general, the highest rates of resistance of Staphylococcus spp. strains were observed for neomycin (16.95\%), penicillin G (10.17\%), and ampicillin (10.17\%). CPS were resistant to neomycin (13.64\%), penicillin G (13.64\%), and ampicillin (13.64\%). The $S$. aureus strains were resistant to neomycin $(37.5 \%)$, kanamycin $(25.0 \%)$, and gentamicin (12.5\%), whereas CNS were resistant to all antimicrobial agents tested (Table 2). Susceptibility to all antimicrobial agents was observed in $76.27 \%$ of the Staphylococcus spp. isolates and one isolate was resistant to all antimicrobial agents tested (Table 3).

\section{Gentamicin residues in milk}

Residues of antimicrobial were not detected in milk samples collected before treatment. The LOD of gentamicin sulfate on Delvotest ${ }^{\circledR}$ SP NT was $200 \mu \mathrm{g} / \mathrm{L}$. Among the 1,440 mammary quarters milk samples analyzed over a period of 12 days after treatment, 103 were positive, 36 contai-

Table 1. Culture results and microbiological profile of milk samples obtained from mammary quarters of cows with clinical and subclinical mastitis before and after treatment

\begin{tabular}{|c|c|c|c|c|c|c|c|c|c|c|}
\hline \multirow[t]{3}{*}{ Item } & \multicolumn{4}{|c|}{ Clinical mastitis } & \multicolumn{4}{|c|}{ Subclinical mastitis } & \multicolumn{2}{|c|}{ Total n (\%) } \\
\hline & \multicolumn{2}{|c|}{${\text { Treated } \mathrm{MQ}^{\mathrm{b}}}$} & \multicolumn{2}{|c|}{ Untreated MQ } & \multicolumn{2}{|c|}{ Treated MQ } & \multicolumn{2}{|c|}{ Untreated MQ } & \multirow[t]{2}{*}{$\mathrm{BT}$} & \multirow[t]{2}{*}{ AT } \\
\hline & $\mathrm{BT}^{\mathrm{c}}$ & $\mathrm{AT}^{\mathrm{d}}$ & BT & $\mathrm{AT}$ & BT & AT & BT & AT & & \\
\hline MQ samples & 16 & 16 & 45 & 45 & 16 & 16 & 43 & 43 & & \\
\hline Noninfected MQ & 6 & 13 & 19 & 16 & 1 & 4 & 6 & 2 & & \\
\hline Infected MQ & 10 & 3 & 26 & 29 & 15 & 12 & 37 & 41 & & \\
\hline Isolates $^{\mathrm{a}}$ & 13 & 3 & 29 & 36 & 21 & 14 & 42 & 52 & $105(100.00)$ & $105(100.00)$ \\
\hline Corynebacterium spp. & 2 & 2 & 9 & 11 & 9 & 7 & 25 & 27 & $45(42.86)$ & $47(44.76)$ \\
\hline Streptococcus spp. & 6 & 0 & 8 & 7 & 6 & 2 & 8 & 10 & $28(26.67)$ & $19(18.10)$ \\
\hline CNS & 2 & 0 & 6 & 3 & 4 & 1 & 6 & 8 & $18(17.14)$ & $12(11.43)$ \\
\hline CPS & 0 & 1 & 3 & 12 & 0 & 3 & 1 & 4 & $4(3.81)$ & $20(19.05)$ \\
\hline S. aureus & 1 & 0 & 1 & 2 & 1 & 1 & 1 & 2 & $4(3.81)$ & $5(4.76)$ \\
\hline Gram-negative Bacilli & 1 & 0 & 0 & 0 & 1 & 0 & 1 & 1 & $3(2.86)$ & $1(0.95)$ \\
\hline Yeasts & 0 & 0 & 1 & 1 & 0 & 0 & 0 & 0 & $1(0.95)$ & $1(0.95)$ \\
\hline Filamentous Fungi & 1 & 0 & 1 & 0 & 0 & 0 & 0 & 0 & $2(1.90)$ & $0(0.00)$ \\
\hline
\end{tabular}

a Inconsistencies between number of infected quarters and number of isolates is due to multiple pathogens isolated in the same quarter, ${ }^{\mathrm{b}} \mathrm{MQ}$ - mammary quarter, ${ }^{\mathrm{c}} \mathrm{BT}$ - before treatment, ${ }^{\mathrm{d}} \mathrm{AT}$ - after treatment. 
Table 2. Antimicrobial resistance of staphylococcal species isolated from milk of cows with clinical and subclinical mastitis

\begin{tabular}{|c|c|c|c|c|}
\hline \multirow{2}{*}{$\begin{array}{l}\text { Antimicrobial / } \\
\text { Concentration }\end{array}$} & \multicolumn{4}{|c|}{ Resistance (\%) } \\
\hline & $\begin{array}{c}\mathrm{CPS}^{\mathrm{a}} \\
(\mathrm{n}=22)\end{array}$ & $\begin{array}{l}\text { S. aureus } \\
(\mathrm{n}=8)\end{array}$ & $\begin{array}{c}\mathrm{CNS}^{\mathrm{b}} \\
(\mathrm{n}=29)\end{array}$ & $\begin{array}{c}\text { Total of } \\
\text { Staphylococcus spp. } \\
(\mathrm{n}=59)\end{array}$ \\
\hline Penicillin G /10UI & 13.64 & 0.00 & 10.34 & 10.17 \\
\hline Ampicillin $/ 10 \mu \mathrm{g}$ & 13,64 & 0.00 & 10.34 & 10,17 \\
\hline Oxacillin $/ 1 \mu \mathrm{g}$ & 0.00 & 0.00 & 3.45 & 1.69 \\
\hline Ceftiofur $/ 30 \mu \mathrm{g}$ & 0.00 & 0.00 & 3.45 & 1.69 \\
\hline Cefaclor $/ 30 \mu \mathrm{g}$ & 0.00 & 0.00 & 3.45 & 1.69 \\
\hline Neomycin $/ 10 \mu \mathrm{g}$ & 13.64 & 37.50 & 13.79 & 16.95 \\
\hline Gentamicin $/ 10 \mu \mathrm{g}$ & 0.00 & 12.50 & 3.45 & 3.39 \\
\hline Kanamycin $/ 30 \mu \mathrm{g}$ & 0.00 & 25.00 & 3.45 & 5.08 \\
\hline
\end{tabular}

a CPS, coagulase-positive staphylococci, ${ }^{\mathrm{b}} \mathrm{CNS}$, coagulase-negative staphylococci.

Table 3. Antimicrobial resistance profile of Staphylococcus spp. strains isolated from mammary quarters of cows with clinical and subclinical mastitis

\begin{tabular}{clcc}
\hline Profile & \multicolumn{1}{c}{ Antimicrobial } & \multicolumn{2}{c}{$\begin{array}{c}\text { Resistance of } \\
\text { Staphylococcus spp. }\end{array}$} \\
\cline { 3 - 4 } & & Number of isolates (n=59) & $\%$ \\
\hline 1 & NEO & 4 & 8,47 \\
2 & PEN, AMP & 2 & 6,78 \\
3 & NEO, KAN & 1 & 3,39 \\
4 & NEO, KAN, GEN & 1 & 1,69 \\
5 & PEN, AMP, NEO & 1 & 1.69 \\
6 & PEN, AMP, NEO, KAN, GEN, & & 1.69
\end{tabular}

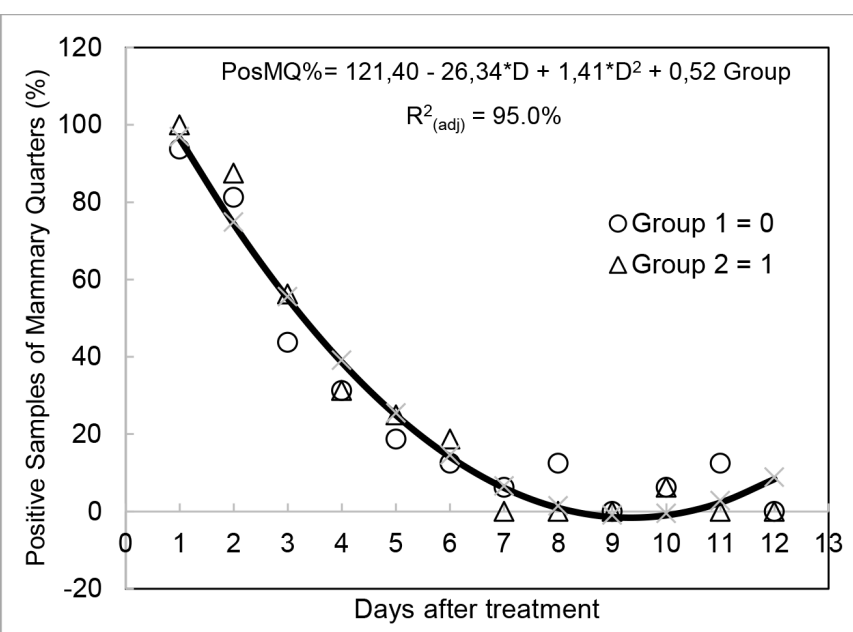

Fig.1. Percentage of mammary quarters testing positive for gentamicin residues according to day of collection after treatment of cows with clinical (group 1) and subclinical mastitis (group 2).

ned residues at the detection limit of the test, and 1,301 were negative. After withdrawal period of four days ( $96 \mathrm{~h}$ ), $24.95 \%$ of quarter milk samples were positive. The lowest frequency of mammary quarter positive samples (1.6\%) was observed 9.3 days after treatment (Fig 1). Variations in the elimination of antibiotic residues were seen thereafter and the samples were negative on the last day of collection after treatment.

Among the 383 milk samples from glass recorder jars obtained over a period of 12 days after treatment, 46 were

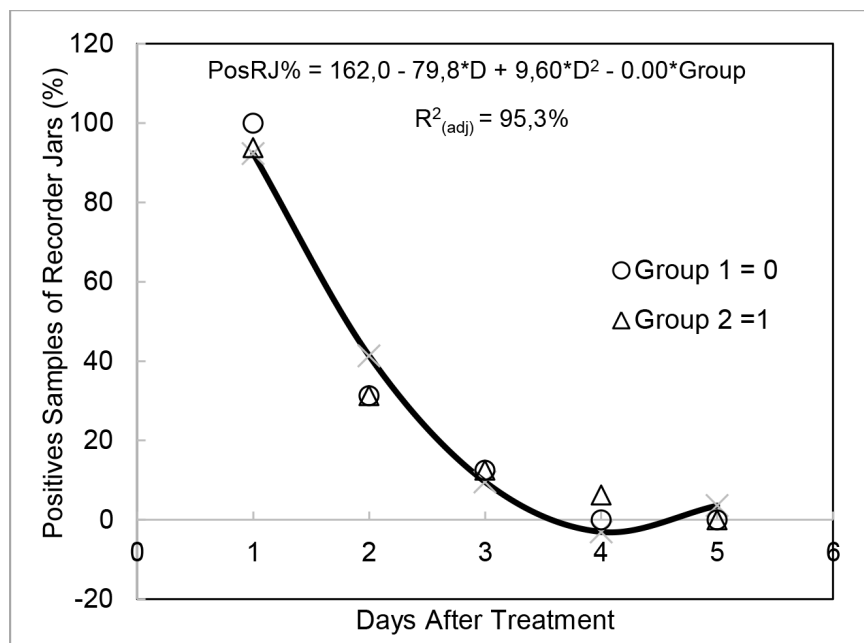

Fig.2. Percentage of calibrated glass recorder jars positive samples for gentamicin residues according to day of collection after treatment of cows with clinical (group 1) and subclinical mastitis (group 2).Table 1. Culture results and microbiological profile of milk samples obtained from mammary quarters of cows with clinical and subclinical mastitis before and after treatment

Table 4. Multivariate binary regression analysis of the frequency of mammary quarter milk samples collected from cows with clinical and subclinical mastitis that tested positive by the Delvotest ${ }^{\circledR}$

\begin{tabular}{|c|c|c|c|c|}
\hline \multicolumn{5}{|c|}{ PosMQ\% ${ }^{\mathrm{a}}=121.40-26.34^{*} \mathrm{D}^{\mathrm{b}}+1.41^{*} \mathrm{D}^{2}+0.52$ Group $^{\mathrm{c}}$} \\
\hline Predictor & $\begin{array}{l}\text { Regression } \\
\text { Coefficient }\end{array}$ & Standard Error & F value & P value \\
\hline Constant & 121.402 & 5.545 & 21.89 & 0.000 \\
\hline Linear Day & -26.343 & 1.889 & -13.95 & 0.000 \\
\hline Quadratic Day & 1.4103 & 0.1414 & 9.97 & 0.000 \\
\hline Group $^{c}$ & 0.521 & 2.983 & 0.17 & 0.863 \\
\hline
\end{tabular}

${ }^{a}$ Regression equation of percentage of positive mammary quarters, ${ }^{b} \mathrm{Col}-$ lection days, ${ }^{\mathrm{c}}$ Animals with clinical or subclinical mastitis, ${ }^{\mathrm{d}}$ Adjusted coefficient of determination.

Table 5. Multivariate binary regression analysis of the frequency of glass recorder jars samples collected from cows with clinical and subclinical mastitis that tested positive by the Delvotest ${ }^{\circledR}$

\begin{tabular}{|c|c|c|c|c|}
\hline \multicolumn{5}{|c|}{ PosRJ $\%^{\mathrm{a}}=162-79.8^{*} \mathrm{D}^{\mathrm{b}}+9.60^{*} \mathrm{D}^{2}-0.00$ Group $^{\mathrm{c}} \mathrm{R}^{2}{ }_{\text {(adj.) }}{ }^{\mathrm{d}}=95,3 \%$} \\
\hline Predictor & $\begin{array}{l}\text { Regression } \\
\text { Coefficient }\end{array}$ & Standard Error & F value & P value \\
\hline Constant & 162.50 & 12.69 & 12.80 & 0.000 \\
\hline Linear Day & -79.77 & 9.471 & -8.42 & 0.000 \\
\hline Quadratic Day & 9.598 & 1.549 & 6.20 & 0.001 \\
\hline Group $^{c}$ & -0.000 & 5.183 & -0.00 & 1.000 \\
\hline
\end{tabular}

a Regression Equation of percentage of positive calibrated glass recorder jars, b Collection days, c Animals with clinical or subclinical mastitis, ${ }^{\mathrm{d}}$ Adjusted coefficient of determination.

positive, 25 contained residues at the detection limit of the test, and 312 were negative. The lowest percentage (3.8\%) of glass recorder jar samples containing gentamicin residues was observed 4.1 days after treatment (Fig.2). No gentamicin residues were detected after this period.

No significant differences in the elimination of gentamicin residues milk from mammary quarters (Table 4) or 
glass recorder jars (Table 5) were observed between cows with clinical and subclinical mastitis. No antimicrobial residues were detected in the 169 milk samples from the cooling tank evaluated by the Delvotest ${ }^{\circledR}$.

\section{DISCUSSION}

\section{Microbiological profile}

The mammary gland is the main reservoir of contagious pathogens in cattle, which are usually transmitted during milking (Bradley 2002). The pathogens most frequently isolated in the present study were Corynebacterium spp., Staphylococcus spp. and Streptococcus spp. These results agree with other studies demonstrating a predominance of these pathogens in cases of bovine mastitis (Tenhagen et al. 2006, Supré et al. 2011). The rates of isolation of Corynebacterium spp. are generally high in herds in which procedures for teat hygiene and disinfection are inadequate (Haltia et al. 2006). On the farm studied here, the teats of cows are cleaned only with water and dried with disposable paper towel. Pre-dipping for antisepsis was not performed during the study, a fact that might have contributed to the transmission of these pathogens during milking.

Staphylococcus is the most frequent genus isolated from milk samples of cows with contagious mastitis and $S$. aureus is the most important species (Fagundes et al. 2010). In the present study, S. aureus presented a low frequency of isolation in the groups of animals studied, whereas CNS was a predominant pathogen of this genus. These microorganisms are less pathogenic than $S$. aureus; however, despite their low pathogenicity, they should be considered causative agents of mastitis and not simply commensal microorganisms of the mammary gland since their isolation from bovine mastitis cases has become increasingly common (Pyörälä \& Taponen 2009).

The isolation of Streptococcus spp. and CNS was less frequent after treatment, mostly in milk samples of treated mammary quarters. These findings are probably related to the efficacy of gentamicin treatment against these pathogens, since Corynebacterium spp., CPS and S. aureus presented higher isolation frequency after treatment, which occurred specially in milk samples of untreated mammary quarters.

\section{Biofilm production and antimicrobial susceptibility}

Biofilm-producing staphylococci have been detected on the teat skin of cows and in the milking units (Fox et al. 2005). Oliveira et al. (2006) detected biofilm formation on CRA in $37.5 \%$ of $S$. aureus strains isolated from cases of subclinical mastitis, a rate similar to that observed in the present study. The authors also found similar biofilm formation by S. epidermidis and S. aureus, in contrast to the present study in which a lower percentage (13.33\%) of CNS produced biofilms. Some of the Staphylococcus spp. strains tested did not produce biofilms on CRA. However, this finding does not rule out the possibility that these strains carry the genes responsible for biofilm formation. Vasudevan et al. (2003) recommended the combination of the CRA method with genotypic tests since biofilm formation on CRA depends on the in vitro conditions. The capacity of sta- phylococci to produce biofilms may confer the adhesion to and colonization of the mammary gland by these microorganisms (Baselga et al. 1993). In addition, biofilm structure and physiological attributes of biofilm organisms confer an inherent resistance to antimicrobial agents (Donlan \& Costerton 2002).

The Staphylococcus spp. strains evaluated by the disc diffusion test exhibited high rates of resistance to neomycin, penicillin G, and ampicillin. In Brazil, betalactams and aminoglycosides antibiotics are frequently used for mastitis treatment. Bal et al. (2010) also reported high resistance to these antibiotics for CNS isolated from milk of cows with subclinical mastitis. Aminoglycosides was the main class of antibiotics used for mastitis treatment in the herd studied. Therefore, the resistance of $S$. aureus isolates only to aminoglycoside antibiotics (gentamicin, kanamycin and neomycin) were expected in the present study. The high rates of resistance to antibiotics could be related to the mastitis control management (Coelho et al. 2009, Bal et al. 2010).

The widespread antimicrobial resistance has become a challenge to the bovine mastitis treatment. Multidrug-resistant Staphylococcus spp. has been isolated from cases of mastitis (Machado et al. 2008, Wang et al. 2015). The finding that CNS were resistant to all antibiotics tested is a matter of concern, since the consumption of milk containing multidrug-resistant microorganisms is a possible source of infection in humans (Lee 2003).

\section{Gentamicin residues in milk}

Treatment of lactating cows with antimicrobials may lead to residues appearing in milk. In Brazil, studies have detected these residues in pasteurized milk, including residues of gentamicin, an antibiotic widely used for intramammary treatment of cows with mastitis (Bando et al. 2009, Spisso et al. 2010). In many countries, gentamicin is not approved for use in dairy cattle and the extralabel use of this drug is not encouraged. However, extralabel use of this antibiotic is in fact very common (Smith et al. 2005, Tan et al. 2009). In contrast, no restrictions exist in Brazil regarding the use of gentamicin for mastitis treatment and its Maximum Residue Limits (MRLs) is not provided by National Sanitary Surveillance Agency of Brazil (ANVISA). In this study, gentamicin sulfate was detected with Delvotest ${ }^{\circledR}$ SP NT at the level of MRL recommended by Codex Alimen-

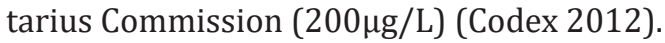

Intramammary antibiotics used during lactation in cattle are usually eliminated rapidly and possess a short withdrawal period. However, studies investigating the persistence of antibiotic residues after the withdrawal period detected residues in $21 \%$ of milk samples after intramammary administration (Smith et al. 2004, Seymour et al. 1988). Antimicrobial residues beyond the withdrawal period were also observed in the mammary quarter milk samples studied here. Antimicrobial residues is a potential health risk to consumers due to problems such as allergic reactions and bacterial resistance and major losses occur in fermented dairy products (Mitchell et al. 1998).

Factors such as the dose of the antibiotic administered and type of vehicle can affect the elimination time and drug 
concentration excreted in milk (Moretain \& Boisseau 1993, Tan et al. 2009). Other factors that influence the persistence of aminoglycoside residues in milk beyond the withdrawal period are the dose interval and the health and physiological state of the animal (Gehring et al. 2005). In the present study, the formulation, dosage and number of applications of gentamicin followed the instructions of the manufacturer of the drug. However, treatment of animals according to manufacturer recommendations has been shown to be insufficient to prevent antibiotic residues in milk after the withdrawal period (McEwen et al. 1992). Considerable variation exists in the concentration of antibiotics in milk from different cows and even between mammary quarters of the same animal (Smith et al. 2004, Bansal et al. 2011). Individual physiological differences between animals such as age, lactation stage, hormone synthesis and milk production interfere with the absorption and excretion rates of antibiotic residues in milk, provoking oscillations in the elimination of these drugs. These differences are more evident in mammary quarters with mastitis compared to healthy mammary quarters (Bansal et al. 2011). In the latter, the variations are due to the physiology of the animal and mammary quarter itself, whereas additional factors exist in animals with mastitis which are related to the pathological state of the gland (Lucas et al. 2009). However, no significant difference were observed in the elimination time of gentamicin between cows with clinical and subclinical mastitis when milk samples from mammary quarters or glass recorder jars were analyzed.

Studies suggest that the presence of an inflammatory process in the mammary gland can influence the persistence of antibiotic residues in milk of treated animals (Lucas et al. 2009, Cagnardi et al. 2010). Mastitis alters vascular permeability and increases the systemic absorption of drugs, increasing the distribution of antibiotics in udder tissues, a fact that may explain the prolonged persistence of drug residues in milk (Gehring \& Smith 2006). Gentamicin is not detected in plasma after intramammary administration to healthy quarters, but is well absorbed in cows with mastitis (Sweeney et al. 1996). The animals studied here had at least one mammary quarter with clinical or subclinical mastitis and inflammation of the gland may have contributed to the greater absorption of gentamicin, prolonging elimination of the drug.

In the present study, the milk of treated animals was discarded and was not sent to the cooling tank of the farm during treatment ( 3 days) and throughout the withdrawal period (4 days) according to the recommendations of the drug manufacturer. The gentamicin residues detected in quarter milk samples after the withdrawal period were not detected by the Delvotest ${ }^{\circledR}$ in calibrated glass recorder jars and in cooling tank samples during the same period. Delvotest $^{\circledR}$ SP NT detects a broad spectrum of antimicrobial, including gentamicin, and is one of the screening tests available for use in quality control programs of dairy industries. The contamination of milk was not detected by the test used, probably because of a dilution effect of the antibiotic in milk from other mammary quarters of the animal or from untreated animals. The higher volume of milk in the tank reduces the detection of positive samples due to a dilution effect of antimicrobial residues (Kang'ethe et al. 2005).

\section{CONCLUSIONS}

The biofilm production and antimicrobial resistance of Staphylococcus isolates were observed in this study and this may lead to persistence of the pathogen in the herd and become a public health problem.

The presence of antimicrobial residues in milk of lactating cows after the withdrawal period affects the milk quality and poses a risk to consumer health.

Therefore, the antimicrobial drugs should be used with a wide margin of safety.

Acknowledgements.- The authors acknowledge the support of the Fundação de Amparo à Pesquisa do Estado de São Paulo (FAPESP) (grant 2012/00855-3)

\section{REFERENCES}

Andrew S.M., Frobish R.A., Paape M.J. \& Maturin L.J. 1997. Evaluation of selected antibiotic residue screening tests for milk from individual cows and examination of factors that affect the probability of false-positive outcomes. J. Dairy Sci. 80:3050-3057.

Andrews J.M. 2009. BSAC standardized disc susceptibility testing method (version 8). J. Antimicrob. Chemother. 64:454-489.

Dowes F.P. \& Ito K. 2001. Compendium of Methods for the Microbiological Examination of Foods. 4th ed., American Public Health Association, Washington, DC. 676p.

Bal E.B.B., Bayar S. \& Bal M.A. 2010. Antimicrobial susceptibilities of coagulase-negative staphylococci (CNS) and streptococci from bovine subclinical mastitis cases. J. Microbiol. 48:267-274.

Bando E., Oliveira R.C., Ferreira G.M.Z. \& Machinski Jr M. 2009. Occurrence of antimicrobial residues in pasteurized milk commercialized in the State of Paraná, Brazil. J. Food Prot. 72:911-914.

Bansal B.K., Bajwa N.S., Randhawa S.S., Ranjan R. \& Dhaliwal P.S. 2011. Elimination of erythromycin in milk after intramammary administration in cows with specific mastitis: relation to dose, milking frequency and udder health. Trop. Anim. Health Prod. 43:323-329.

Baselga R., Albizu I., De La Cruz M., Del Cacho E., Barberan M. \& Amorena B. 1993. Phase variation of slime production in Staphylococcus aureus: implications in colonization and virulence. Infect. Immun. 61:4857-4862.

Bradley A.J. 2002. Bovine mastitis: an evolving disease. Vet. J. 164:1-13.

Cagnardi P., Villa R., Gallo M., Locatelli C., Carli S., Moroni P. \& Zonca A. 2010. Cefoperazone sodium preparation behavior after intramammary administration in healthy and infected cows. J. Vet. Sci. 93:4105-4110.

CLSI 2012. Performance Standards for Antimicrobial Susceptibility Testing. CLSI Document M100-S13. Clinical and Laboratory Standards Institute, Wayne, PA.

Coelho S.M.O., Reinoso E., Pereira I.A., Soares L.C., Demo M., Bogni C. \& Souza M.M.S. 2009. Virulence factors and antimicrobial resistance of Staphylococcus aureus isolated from bovine mastitis in Rio de Janeiro. Pesq. Vet. Bras. 29:369-374.

Codex Alimentarius Commission 2012. Maximum residue limits for veterinary drugs in foods updated as at the 35th session of the Codex Alimentarius Commission. <http://www.codexalimentarius.org/standards/veterinary-drugs-mrls/en/> (Accessed on August 15, 2015)

Daniel R.C.W., Barnum D.A. \& Rennie J.C. 1966. Variation in modified California mastitis test scores in dairy cattle. J. Dairy Sci. 49:1226-1229.

Donlan R.M. \& Costerton J.W. 2002. Biofilms: survival mechanisms of clinically relevant microorganisms. Clin. Microbiol. Rev. 15:67-193.

Fagundes H., Barchesi L., Nader Filho A., Ferreira L.M. \& Oliveira C.A.F. 2010. Occurrence of Staphylococcus aureus in raw milk produced in dairy farms in São Paulo state, Brazil. Braz. J. Microbiol. 41:376-380. 
Fox L.K., Zadoks R.N. \& Gaskins C.T. 2005. Biofilm production by Staphylococcus aureus associated with intramammary infection. Vet Microbiol. 107:295-299.

Freeman D.J., Falkiner F.R. \& Keane C.T. 1989. New method for detecting slime production by coagulase negative staphylococci. J. Clin. Pathol. 42:872-874.

Gehring R. \& Smith G.W. 2006. An overview of factors affecting the disposition of intramammary preparations used to treat bovine mastitis. J. Vet. Pharmacol. Ther. 29:237-241.

Gehring R., Haskell S.R., Payne M.A., Craigmill AL., Webb A.I. \& Riviere J.E. 2005. Aminoglycoside residues in food of animal origin. J. Am. Vet. Med. Assoc. 227:63-66.

Gomes F. \& Henriques M. 2015. Control of bovine mastitis: old and recent therapeutic approaches. Curr. Microbiol. 72(4):377-382.

Haltia L., Honkanen-Buzalski T., Spiridonova I., Olkonen A. \& Myllys V. 2006. A study of bovine mastitis, milking procedures and management practices on 25 Estonian dairy herds. Acta Vet Scand. 48:22.

Kang J.H., Jin J.H. \& Kondo F. 2005. False-positive outcome and drug residue in milk samples over withdrawal times. J. Dairy Sci. 88:908-913.

Kang'ethe E.K., Aboge G.O., Arimi S.M., Kanja L.W., Omore A.O. \& McDermott J.J. 2005. Investigation of the risk of consuming marketed milk with antimicrobial residues in Kenya. Food Control 16:349-355.

Lee J.H. 2003. Methicillin (oxacillin)-resistant Staphylococcus aureus strains isolated from major food animals and their potential transmission to humans. Appl. Environ. Microbiol. 69:6489-6494.

Lucas M.F., Errecalde J.O. \& Mestorino N. 2009. Pharmacokinetics of azithromycin in lactating dairy cows with subclinical mastitis caused by Staphylococcus aureus. J. Vet. Pharmacol. Ther. 33:132-140.

Machado T.R.O., Correa M.G. \& Marin J.M. 2008. Antimicrobial susceptibility of coagulase-negative Staphylococci isolated from mastitic cattle in Brazil. Arq. Bras. Med. Vet. Zootec. 60:278-282.

McEwen S.A., Black W.D. \& Meek A.H. 1992. Antibiotic residues (bacterial inhibitory substances) in the milk of cows treated under label and extra-label conditions. Can. Vet. J. 33:527-534.

Melchior M.B. 2011. Bovine mastitis and biofilms, p.205-221. In: Percival S., Knottenbelt D. \& Cochrane C. (Eds), Biofilms and Veterinary Medicine. Vol.6, Springer-Verlag, Heidelberg.

Minitab Statistical Software 15.1.3, 2010. <www.minitab.com> Accessed 23.04.15.

Mitchell J.M., Griffiths M.W., McEwen S.A., McNab W.B. \& Yee A.J. 1998. Antimicrobial Drug Residues in Milk and Meat: Causes, Concerns, Prevalence, Regulations, Tests, and Test Performance. J. Food Prot. 61:742-756.

Moretain J.P. \& Boisseau J. 1993. Elimination of aminoglycoside antibiotics in milk following intramammary administration. Vet. Quart. 15:112117.

Oliveira M., Bexiga R., Nunes S.F., Carneiro C., Cavaco L.M., Bernardo F. \& Vilela C.L. 2006. Biofilm-forming ability profiling of Staphylococcus aureus and Staphylococcus epidermidis mastitis isolates. Vet. Microbiol. 118:133-140.

Peton V. \& Le Loir Y. 2014. Staphylococcus aureus in veterinary medicine. Infect. Genet. Evol. 21:602-615

Pyörälä S. \& Taponen S. 2009. Coagulase-negative staphylococci - emerging mastitis pathogens. Vet. Microbiol. 134:3-8.

Seymour E.H., Jones G.M. \& McGilliard M.L. 1988. Persistence of residues in milk following antibiotic treatment of dairy cattle. J. Dairy Sci. 71:2292-2296.

Smith G.W., Gehring R., Craigmill A.L., Weeb A.I. \& Riviere J.E. 2005. Extralabel intramammary use of drugs in dairy cattle. J. Am. Vet. Med. Assoc. 266:1994-1996.

Smith G.W., Gehring R., Riviere J.E., Yeatts J.L. \& Baynes R.E. 2004. Elimination kinetics of ceftiofur hydrochloride after intramammary administration in lactating dairy cows. J. Am. Vet. Med. Assoc. 224:1827-1830.

Spisso B.F., Monteiro M.A., Pereira M.U., Ferreira R.G., Da Costa R.P., Ávila Cruz T. \& Da Nóbrega A.W. 2010. Pilot survey of commercial pasteurized milk consumed in the metropolitan area of Rio de Janeiro, Brazil, for tetracyclines residues, including the 4-epimers of oxytetracycline, tetracycline and chlortetracycline. Food Addit. Contam. B, Surveill. 3:220-227.

Supré K., Haesebrouck F., Zadoks R.N., Vaneechoutte M., Piepers S. \& De Vliegher S. 2011. Some coagulase-negative Staphylococcus species affect udder health more than others. J. Dairy Sci. 94:2329-2340.

Sweeney R.W., Fennell M.A., Smith C.M. \& Bardalaye P.C. 1996. Systemic absorption of gentamicin following intramammary administration to cows with mastitis. J. Vet. Pharmacol. Ther. 19:155-157.

Tan X., Jiang Y.W., Huang Y.J. \& Hu S.H. 2009. Persistence of gentamicin residues in milk after the intramammary treatment of lactating cows for mastitis. J. Zhejiang Univ. Sci. B 10:280-284.

Tenhagen B.A., Köster G., Wallmann J. \& Heuwieser W. 2006. Prevalence of mastitis pathogens and their resistance against antimicrobial agents in dairy cows in Brandenburg, Germany. J. Dairy Sci. 89:2542-2551.

Vasudevan P., Kumar M., Nair M., Annamalai T. \& Venkitanarayanan K.S. 2003. Phenotypic and genotypic characterization of bovine mastitis isolates of Staphylococcus aureus for biofilm formation. Vet. Microbiol. 92:179-185

Wang D., Wang Z., Yan Z., Wu J., Ali T., Li J., Lv Y. \& Han B. 2015. Bovine mastitis Staphylococcus aureus: antibiotic susceptibility profile, resistance genes and molecular typing of methicillin-resistant and methicillin-sensitive strains in China. Infect. Genet. Evol. 31:9-16 